MECHANICAL ENGINEERING

DOI 10.5862/JEST.249.12

УДК 621.88 .084 .4

A.V. Kuschenko, A.Ya. Bashkarev

\title{
CONTROL OF FRICTION PROPERTIES IN POLYAMIDE COATINGS IN TENSION JOINTS
}

\section{А.В. Кущенко, А.Я. Башкареб

\begin{abstract}
КОНТРОЛЬ СВОЙСТВ ТРЕНИЯ В ПОЛИАМИДНЫХ ПОКРЫТИЯХ НАПРЯЖЕННЫХ СОЕДИНЕНИЙ
\end{abstract}

\begin{abstract}
Tension joints are used to transfer twisting moments and axial loads due to friction forces, which occur on contacting surfaces as a result of their elastic deformation created by tension in assembly. During operation, joints made of steel elements deteriorate due to fretting corrosion caused by alternating loads, common for many types of machines and equipment. One of the ways to fight this condition is to apply thin-layer polymer coatings. The paper presents the results of research in adhesion strength and the static coefficient of friction of a thin-layer polyamide coating and polyamide-based composites on steel. It is revealed that the best friction and adhesion properties are demonstrated by a polyamide composite with $20-40 \%$ of mass fraction of red iron oxide. Its static coefficient of friction on steel is comparable to the static coefficient of friction of steel on steel while adhesion to a steel surface on failure is $40 \%$ higher than that of a pure polyamide coating.
\end{abstract}

TENSION JOINTS; POLYAMIDE COATINGS; ADHESION; STATIC COEFFICIENT OF FRICTION; FRETTING CORROSION.

\begin{abstract}
Напряженные соединения используются, чтобы передать крутящий момент и осевую нагрузку благодаря силам трения, которые вознькают при контакте с поверхностями в результате их упругой деформации, созданной комплексными напряжениями. При эксплуатации соединения, изготовленные из стальных элементов, ухудшаются из-за фреттинг коррозии, вызванной переменной нагрузкой, характерной для многих типов машин и оборудования. Один из способов борьбы с этим явлением - применение тонкослойных полимерных покрытий. Статья представляет результаты исследований адгезионной прочности и статического коэффициента трения тонкослойного полиамидного покрытия и композитов на основе полиамида на стальных соединениях. Выявлено, что лучшие свойства трения и адгезии имеет полиамидный композит с $20-40 \%$ масс фракции красной окиси железа. Его статический коэффициент трения по стали сопоставим со статическим коэффициентом трения стали по стали, в то время как адгезия к стальной поверхности на $40 \%$ больше, чем у чисто полиамидного покрытия.
\end{abstract}

НАПРЯЖЕННЫЕ СОЕДИНЕНИЯ; ПОЛИАМИДНЫЕ ПОКРЫТИЯ; АДГЕЗИЯ; СТАТИЧЕСКИЙ КОЭФФИЦИЕНТ ТРЕНИЯ; ФРЕТТИНГ КОРРОЗИЯ.

\section{Introduction}

It is common knowledge that tension joints are used to transfer twisting moments and axial forces without accessory mountings. Immobility of parts in relation to each other is ensured with friction forces that appear on contact surfaces due to their elastic deformation created by tension in the assembled joint.

Demountable tension joints are simple and easy to make and their expected service life is long. But it is known [1-3] that deterioration of such joints made 
of steel parts can occur earlier than the service life has expired due to fretting corrosion which develops because of alternating loads, common for a lot of machinery. One of the effective methods both to protect tension joints from fretting corrosion and to repair damaged ones may be to use polymer materials, in particular, polyamides.

It was believed earlier that if polymers are used in tension joints, tension may disappear due to relaxation phenomena. However, for some polymers, for example, polyamides, which belong to the group of elastomers, the Poisson's ratio is practically equal to 0,5 , i.e. in terms of the classical theory of elasticity they are practically an incompressible material. In reality they easily deform due to plastic deformations that occur without change of volume. If deformation occurs while there is no capability for the material to move, i.e. no plastic shears are possible, then deformation of polyamides can only happen thanks to change in intermolecular distances, which requires considerable forces comparable to deformation for-ces of metallic supra-molecular structures. Herein, such deformation can be considered almost ideally elastic.

Accordingly, thin-layer polyamide coatings or polyamide-based composite coatings can be applied both to protect new tension joints from fretting-corrosion and to repair damaged ones. So, the target of the research is the new design of tension joints with application of thin-layer coatings made of polyamide or polyamide-based composites (fig. 1) to increase durability and reparability of machine parts.

The objective of this paper is to conduct an experimental study of friction characteristics of thinlayer $(0.1-0.5 \mathrm{~mm})$ polymer coatings made of different types of polyamides and to search for ways to increase their static coefficient of friction on steel.

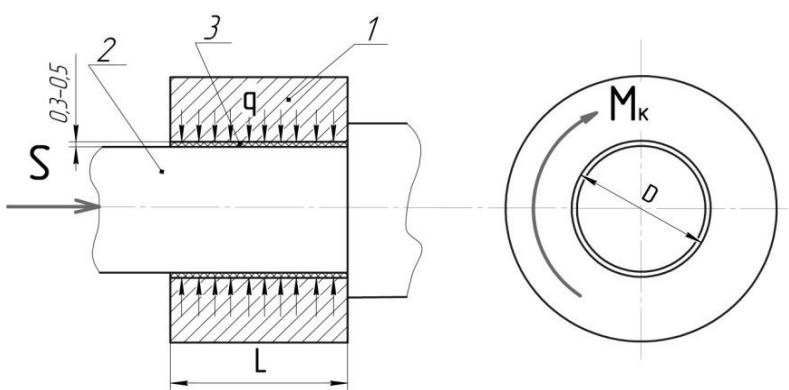

Fig. 1. Application scheme of a polyamide coating for tension joints: 1 -bush; 2 - shaft; 3 - thin-layer polyamide coating of the shaft; $S$ - axial load; $M_{\mathrm{t}}$ - external twisting moment; $q$ - radial pressure in the contact area; $D$ - nominal bore diameter; $L$ - length of the articulation

\section{Methods and Materials}

It is known [4-6] that polyamides are widely used in friction units of machines as antifriction materials, since their coefficient of sliding friction is rather low and their operating capabilities are quite high [7, 8]. However, so far there has been no experience in applying thin-layer polyamide coatings in tension joints, and traditional methods for increasing friction characteristics by adding metal chips, asbestos etc. [6] in polyamide cannot be used in this case due to technological specifics of thin-layer coatings application.

In order to assess friction properties of thin-layer polyamide coatings, their static coefficient of friction on steel was measured depending on the pressure in the friction area. The range of $0,065-0,53 \mathrm{~mm}$ thick coatings made of PA-6, PA-6/66, PA-68 polyamides were used in the experiments.

The value of the static coefficient of friction was measured on a "IR 5047-50-11" test machine. Samples with polyamide coating had been made. Force was exerted through steel plates, which allowed creating pressure in the friction area up to $30 \mathrm{MPa}$. The samples with the loader were fixed in the transverse beam of the test machine and were affected by a growing load, to the extent when the steel plates got to slide on the polymer coating. A computer recorded the loading diagram.

\section{Experiment Results}

According to the results of the experiments, the static coefficient of friction of the polyamide coating on steel is not constant. It decreases as the pressure is growing and, at the same time, it is 30-40\% lower than the coefficient for the pair "steel-steel" (fig. 2).

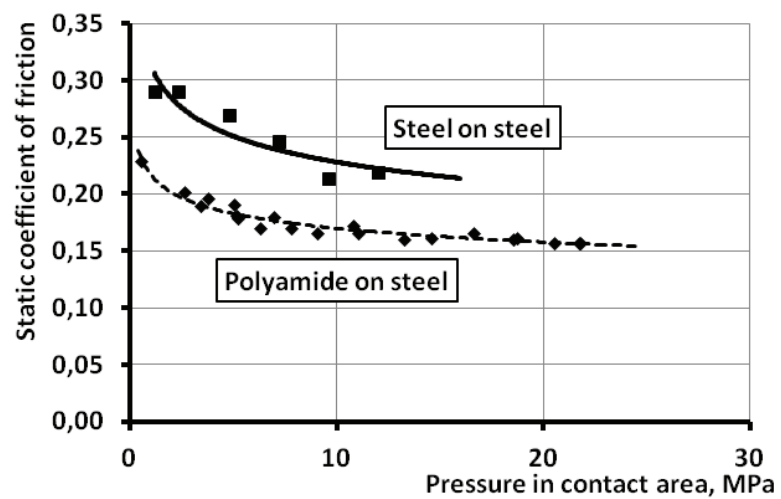

Fig. 2. Static coefficients of friction of polyamide on steel and steel on steel 
The experiments have also revealed that the static coefficient of friction of polyamide on steel depends not only on the pressure in the friction area, but also on how thick the polyamide layer is. In case the thickness of the layer is decreased from 0,12 down to $0,065 \mathrm{~mm}$ in the whole range of pressures from 1 to $30 \mathrm{MPa}$, it is observed that the static coefficient of friction grows (for example, from 0,17 up to 0,25 at the pressure of $1 \mathrm{MPa}$ in the friction area and from 0,08 up to 0,14 at $30 \mathrm{MPa}$ ). In case the coating is more than $0,12 \mathrm{~mm}$ thick, the static coefficient of friction of polyamide on steel is constant (fig. 3).

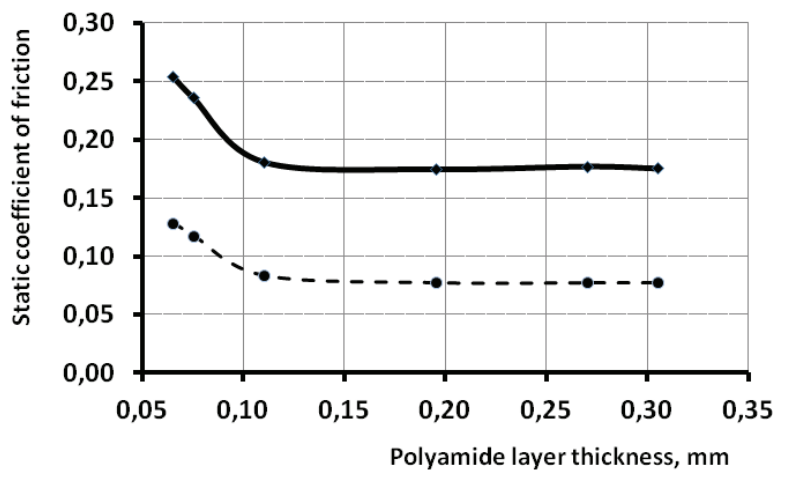

Fig. 3. Change in the value of the static coefficient of friction of polyamide on steel depending on the thickness of the layer. (The solid line is at the pressure of $1 \mathrm{MPa}$ in the friction area, the dashed line is at $30 \mathrm{MPa}$ )

A lower static coefficient of friction of polyamide on steel than that of the pair "steel-steel" gives evidence that when thin-layer polymer coatings are used in tension joints, a method must be found to increase the static coefficient of friction of polymer on steel with the use of different additives, i.e. by creating composite mixtures.

a)

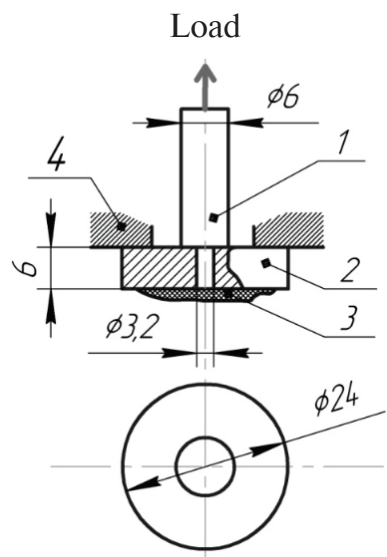

b)

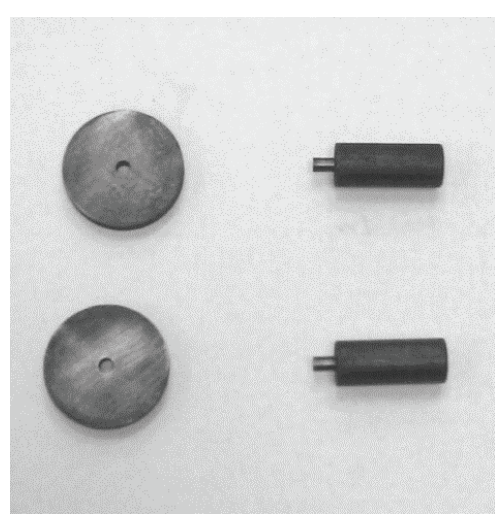

The use of polyamide coatings and polyamidebased composites in tension joints can be limited due to insufficient adhesion of the polyamide layer to the steel substrate. So, measurements of the value of adhesion were made, i.e. measurements of the ultimate strength of the coating adhesion to steel by simple stresses. There are a lot of papers dedicated to adhesion of polymers to steel [11, 12, 15-17]. However, these studies have been made for polymer slide bearings rather than coatings in tension joints.

Adhesion has been researched by a well-known method of breaking a steel pin from the deposited polymer compound [8]. The loading diagram and general view of the test samples are given in figure 4 . The samples represent pivot 1 , which finishes in a 3 $\mathrm{mm}$ pin. Disc 2 is planted on the pin with a sliding attachment. The surface of the disc and the end of the pin coincide. Polymer or polymer-based composite is applied on the surface of the disc. In order to lower friction between the pin and the hole of the disc, the pin is covered with graphite lubrication.

The value of breaking stress of the end of the pin from polymer was measured on a "IR 5047-50-11" test machine. For this, the disc of the sample was fixed in the clench of the machine transverse beam and the pivot of the sample was exerted with a growing force to the extent when the pin broke off polymer. At the same time a computer recorded the loading diagram.

As applied to the operation conditions of polyamide coatings in tension joints, adhesion properties to steel of pure polyamide and polyamide-based compositions with lead oxide, red iron oxide and powdered glass were studied.

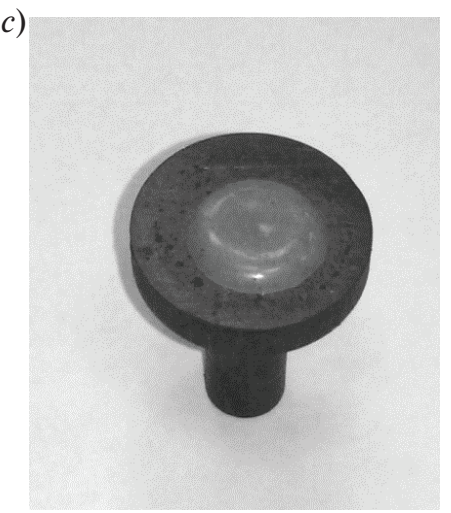

Fig. 4. The loading diagram and general view of the samples for defining the adhesion value: 1 - pivot; 2 - disc; 3 - polymer coating; 4 - block stop 
According to the results of the experiment (fig. 5): the value of adhesion on failure for a pure polyamide coating is about $35 \mathrm{MPa}$;

with the values of mass content of lead oxide up to $20 \%$, the value of adhesion of this composite to steel practically does not change and can be defined as $35 \mathrm{MPa}$ and goes down dramatically if the content is larger;

with the values of mass content of powdered glass up to $15 \%$, the value of adhesion of this composite to steel grows by approximately $20 \%$ (up to $40 \mathrm{MPa}$ ) and goes down if the content is larger;

with the values of mass content of red iron oxide up to $30 \%$, the value of adhesion of this composite to steel grows by approximately $60 \%$ (up to $50 \mathrm{MPa}$ ) and goes down if the content is larger.

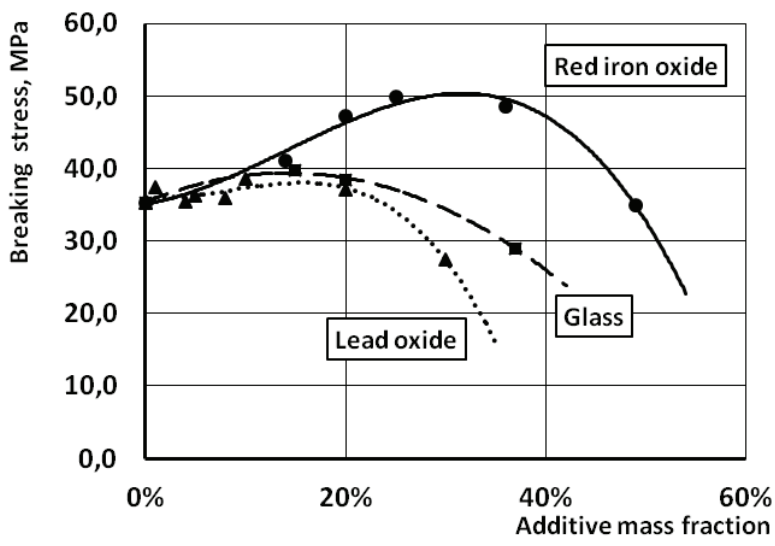

Fig. 5. Change of adhesive characteristics of polyamide-based composites depending on the type and mass fraction of additives

The measured static coefficient of fraction of the polyamide-based composite which contained $20 \%$ of red iron oxide showed that its values coincided with the corresponding ones for the pair "steel-steel" (fig. 6).

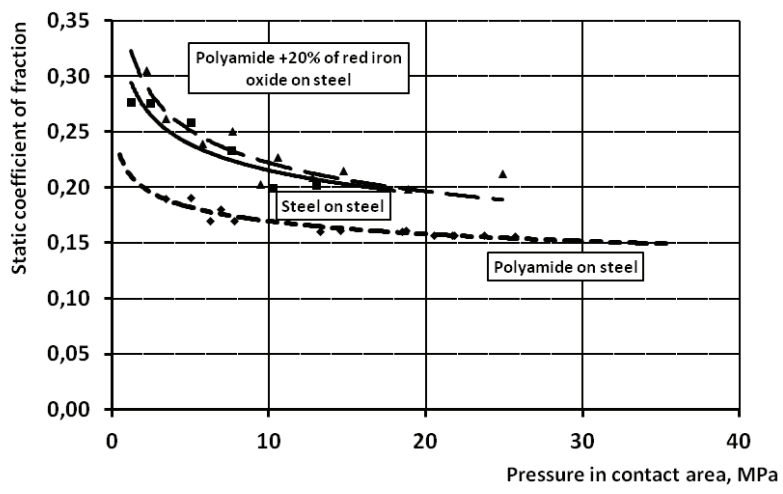

Fig. 6. Change of the static coefficient of fraction of polyamide based composite with $20 \%$ of red iron oxide on steel because of pressure in the contact area

\section{Discussion of the results}

According to the molecular-mechanical theory of friction [14], friction force forms due to:

resistance to motion of one body towards another due to interatomic and intermolecular interactions in the actual contact areas of the bodies, i.e. adhesion forces;

when solid bodies come in contact due to their varying stiffness or their inhomogeneous properties in different areas and due to varying stiffness of individual micro-irregularities, stiffer elements penetrate less stiff sections. As relative motion begins, more solid sections deform the surface of one of the bodies. Resistance forces, which occur at that time, can be called deformation components of friction.

According to this theory, the coefficient of sliding friction $f_{f}$ can be presented as:

$$
f_{f}=f_{0}\left(1+\frac{S_{a} p_{0}}{N}\right)
$$

where $p_{0}$ is the specific force of molecular attraction, $S_{a}$ - area of actual contact, $N-$ load, $f_{0}-$ the value of the coefficient of sliding friction as $p_{0}=0$.

Thus, when the load grows, the contact area remains constant and the pressure in the friction area grows, the coefficient of friction must decrease. The intensity of this decrease depends on mechanical and adhesive properties of the materials, which also affect the intensity with which the surface area of actual contact is changing due to a growing load.

The obtained results are confirmed with the data from literature sources, according to which the coefficient of sliding friction of polyamide goes down if pressure grows in the friction area. For instance, [6] for PA-68 polyamide the coefficient of sliding friction changes from 0,15 at the pressure of 2,5 MPa to 0,07 at 9,0 $\mathrm{MPa}$, while for policaproctalam it varies from 0,25 to 0,15 .

The results of the experiments confirm the assumption $[9,10]$ that in case thin-layer coatings are applied on steel substrate, strong compression strains (up to $400 \mathrm{MPa}$ ) develop in $0,1 \mathrm{~mm}$ thick polyamide layer which directly adjoins the steel surface. This happens due to coordination bonds between iron ions, which are part of red iron oxide and steel substrate, and nitrogen atoms in polyamide hotmelt. As a result, surface hardness grows dramatically and so does the mechanical component in friction forces and, consequently, adhesion increases. There are no iron ions in lead oxide or powdered glass. 


\section{Conclusions}

1. The values have been determined experimentally for the static coefficient of friction and adhesion strength on failure of thin-layer polyamide and some polyamide-based composite coatings on steel surfaces.

2. It has been identified that the static coefficient of friction for the pair "polyamide - steel" is $40 \%$ lower than that for the pair "steel - steel".

3 . It has been revealed how the effect of polyamide coating layer thickness impacts the static coefficient of friction on steel. With coating thickness more than $0,12 \mathrm{~mm}$, the static coefficient of friction of polyamide on steel does not change.

4. In case additives such as red iron oxide are added to polyamide, a composite forms, whose adhesion to steel is bigger than that of pure polyamide, up to $50 \%$ of red iron oxide mass fraction. Adhesion reaches maximum values of $50 \mathrm{MPa}$ with red iron oxide content of $30 \%$ in mass fraction.

5. In tension joints it is reasonable to use thinlayer coatings consisting of a polyamide-based composite with $20-40 \%$ of red iron oxide mass fraction, rather than pure polyamide.

\section{REFERENCES}

1. Alisin V.V. [et al.]. Friction, Wear and Lubrication / Edited by Kragelsky I.V., Alisin V.V. Moscow: Mechanical Engineering. 1978. 400 s. (rus.)

2. Grechischev E.S., Ilyashenko A.A. Tension Joints. Calculations, Design, Manufacturing, Moscow. Mechanical Engineering, 1981. - 247 s. (rus.)

3. Kaisa A.M. Joda Increasing Durability and Maintainability of Construction Machines Parts with Polymer Materials: PhD thesis. / Leningrad, LPI, 1984.

4. Bilik M.M., Slyudikova N.N. Antifriction Properties of Some Polymer Materials in Monolith and Thin-Layer Coating. Polymers in Manufacturing Industry. Homel', 1968. P. 26-32.

5. Stukach A.V. Research in Efficiency of Friction Units with Polymer Coatings in Caterpillar Tread of Construction Machines: PhD thesis / Leningrad, LPI, 1980. 125 s. (rus.)

6. Chichinadze A.V. [et al.] Polymers in Friction Units of Machines and Devices: Reference book / Edited by A.V. Chichinadze. Moscow: Mechanical Engineering, 1988. 328 s. (rus.)

7. Mitrovich V.P. Research In Friction of Polyamides on Steel. Moscow, 1963. 96 s. (rus.)

8. Stukach A.V. Research and Control over the Properties of Polymer Coatings in Their Formation When Worn Surfaces Are Repaired and Given Antifriction Properties. Scientific and technical journal of St. Petersburg State University of Service and Economics "Engineering

\section{СПИСОК ЛИТЕРАТУРЫ}

1. Алисин В.В. [и др.] Трение, износ и скольжение / Под ред. Крагельского И.В., Алисина В.В. М.: Машиностроение, 1978.400 с.

2. Гречищев Е.С., Пященко А.А. Напряженные соединения. Расчеты, конструирование, производство. М.: Машиностроение, 1981. 247 с.

3. Кайса А.М. Джожа. Повышение работоспособности и надежности деталей машин с полимерными материалами: Дисс. ... канд техн. наук / Л., ЛПИ, 1984. 122 c.

4. Bilik M.M., Slyudikova N.N. Antifriction Properties of Some Polymer Materials in Monolith and Thin-Layer and Technological Problems of Service”. St. Petersburg, 2009. № 10. S. 42-50. (rus.)

9. Vettegren' V.I. [et al.] Tension and Wear Resistance of Polymer Coatings. Solid State Physics. Vol. 57, issue7. St. Petersburg, Ioffe Institute. 2015. S. 1365-1372.

10. Petrov V.A., Bashkarev A.Y., Vettegren' V.I. Physics of Forecasting Construction Materials Durability. St. Petersburg: Politekhnika, 1993. 475 s. Lems of Service”. St. Petersburg, 2009. № 10. S. 42-50. (rus.)

11. Berlin A.A., Basin I.V. Fundamentals of Polymer Adhesion. Moscow: Chemistry, 1974. $392 \mathrm{~s}$.

12. Ivan'kov S.A., Bashkarev A.Y., About Durability and Strength of Composites. Scientific and Technical Journal of SPbPU. St. Petersburg, Publishing House of SPbPU. 2011. № 4 (110). S. 196-199. (rus.)

13. Ivanov A.S., Popov B.A. Calculation of Tension Joints Given Contact Stiffness of Conjugated Surfaces. Mechanical Engineering Journal. 2005. № 4. S. 31-36. (rus.)

14. Chichinadze A.V. [et al.] Fundamentals of Tribology / Edited by Chichinadze A.V. Moscow, Mechanical Engineering, 2001. 663 s. (rus.)

15. Bikermann J.J. The science of Adhesives Joints, New York: Academic Press, 1968. 241 p.

16. Gardon J. Treatise on adhesion and adhesives. New York, Academic Press 1967, P. 67-70.

17. Pakham D., Grad R. Aspects of adhesion. London, 1971, № 6. P. 127-149.

Coating // Polymers in Manufacturing Industry, Homel', 1968. P. 26-32.

5. Стукач А.В. Исследование эффективности узлов трения с полимерными покрытиями в конструкциях машин фирмы Катерпиллер: Дисс. ... канд техн. наук / Л., ЛПИ, 1980. 125 с.

6. Чичинадзе А.В. [и др.] Полимеры в узлах трения машин и механизмов / Под ред. А.В. Чичинадзе, М.: Машиностроение, 1988.328 с.

7. Митрович В.П. Исследование трения полиамидов по стали. М.: Машиностроение, 1963. 96 с. 
8. Стукач А.В. Исследование и контроль свойств полимерных покрытий при их образовании на рабочих поверхностях в процессе восстановления и получаемые антифрикционные свойства // Журнал Санкт-Петербургского государственного университета сервиса и экономики "Инженерные и технологические проблемы сервиса”. Санкт-Петербург. 2009. № 10. C. 42-50.

9. Vettegren' V.I. [et al.] Tension and Wear Resistance of Polymer Coatings // Solid State Physics. 2015. Vol. 57, Is. 7. P. $1365-1372$.

10. Петров В.А., Башкарев А.Я., Веттегрен В.И. Физика прогнозирования работоспособности конструкционных материалов. СПб.: Политехника, 1993. $475 \mathrm{c}$

11. Берлин А.А., Басин И.В. Основы полимерной адгезии. М.: Химия, 1974. 392 с.
12. Иваньков С.А., Башкарев А.Я. О работоспособности и прочности композитов // Научнотехнические ведомости СПбГПУ. 2011. № 4(110). C. 196-199.

13. Иванов А.С., Попов В.А. Расчет напряженных соединений с заданной жесткостью контакта сопрягаемых поверхностей // Машиностроение, 2005. № 4. С. $31-36$.

14. Чичинадзе А.В. [и др.]. Основы трибологии / Под ред. А.В. Чичивадзе. М.: Машиностроение, 2001. $663 \mathrm{c}$.

15. Bikermann J.J. The science of Adhesives Joints, New York: Academic Press, 1968. 241 p.

16. Gardon J. Treatise on adhesion and adhesives. New York, Academic Press 1967. P. 67-70.

17. Pakham D., Grad R. Aspects of adhesion. London, 1971. № 6. P. 127-149.

\section{СВЕДЕНИЯ ОБ АВТОРАX/AUTHORS}

KUSCHENKO Alexandra V. - post graduate student of the department "Transport and Technology Systems", Institute of Metallurgy, Mechanical Engineering and Transport, Peter the Great St. Petersburg.

State Autonomous Polytechnic University, Russia, St. Petersburg, 195251, Polytekhnicheskaya Street, 29.

E-mail: aleksandra.kushchenko@rambler.ru

КУЩЕНКО Александра Владимировна - аспирант Санкт-Петербургского политехнического университета Петра Великого.

195251, Россия, г. Санкт-Петербург, Политехническая ул., 29.

E-mail: aleksandra.kushchenko@rambler.ru

BASHKAREV Albert Ya. - Doctor of Technical Sciences Professor of the department "Transport and Technology Systems", Institute of Metallurgy, Mechanical Engineering and Transport, Peter the Great St. Petersburg

Polytechnic University. 29 Politechnicheskaya St., St. Petersburg, 195251, Russia.

E-mail: bashkarev@spbstu.ru

БАШКАРЕВ Альберт Яковлевич - доктор технических наук советник при ректорате Санкт-

Петербургского политехнического университета Петра Великого.

195251, Россия, г. Санкт-Петербург, Политехническая ул., 29

E-mail: bashkarev@spbstu.ruaa 